Debreceni Jogi Múhely 2021. (XVIII.) 3-4.

Debreceni Egyetem, Állam- és Jogtudományi Kar, Debrecen

(University of Debrecen, Faculty of Law, Debrecen)

DOI 10.24169/DJM/2021/3-4/3

Joó László Ádám

PhD hallgató

Debreceni Egyetem, Marton Géza Állam-és Jogtudományi Doktori Iskola

\title{
A MÁSODIK BÉCSI DÖNTÉSSEL VISSZATÉRT ORSZÁGRÉSZEK TÖRVÉNYKEZÉSI RENDSZERE
}

Debreceni Jogi Múhely, 2021. évi (XVIII. évfolyam) 3-4. szám (2022. február 15.)

DOI 10.24169/DJM/2021/3-4/3

\begin{abstract}
The reconstruction of the justice system in the eastern and Transylvanian parts of the country, which returned in 1940, is currently a barely explored area in the Hungarian constitutional history. In this study, my aim is to present through the court system the enormous task of the legislator, which was implemented eighty years ago. This topic can be included in my researches on the legal system of the area, not only from the constitutional history point of view, but also when examining the enforcement of extended private law. The judicial practice was highly influenced by the legal knowledge of judges and became frequently questionable during the period of the extension of the Hungarian private law (1941-42) and it was closely related to their legal activities prior to their appointment.

In the present study, I follow the changes that took place between the two Romanian occupations (1918-19 and 1944) in the two parts of the country that returned at the same time, highlighting the period when the territories were ruled by the Hungarian state for four years. I use the relevant legislation, archival documents and the literature published so far. Therefore, this study was not intended to be a summary of them, but a synthesis containing new conclusions.
\end{abstract}

Keywords: Second Vienna Award, Northern Transylvania, jurisdiction, courts, judges

Absztrakt: Az igazságszolgáltatás szervezetrendszerének az 1940-ben visszatért keleti és erdélyi országrészeken történt újjászervezése jelenleg alig feltárt területe a magyar alkotmánytörténetnek, így e tanulmányomban a bírósági szervezeten keresztül megpróbálom bemutatni azt a hatalmas feladatot, amelyet a jogalkotó nyolcvan évvel ezelőtt végrehajtott. A terület jogrendszerének feltárására irányuló kutatásaimba nemcsak alkotmánytörténeti szempontból illeszthető be ez a téma, hanem a kiterjesztett magánjog érvényesülésének vizsgálatánál sem mellőzhető. Az ítélkezési gyakorlatot nagyban befolyásolta a bírók jogismerete, amely a magyarországi magánjog kiterjesztésének időszakában (1941-42) gyakran kérdésessé vált, és szorosan kapcsolódott a kinevezésük előtti jogászi tevékenységükhöz.

Jelen tanulmányban azokat a változásokat követem végig, amelyek a két román megszállás (1918-19 és 1944) között mentek végbe az említett két, egyszerre visszatért országrészen, kiemelve azt az időszakot, amelyben ezekre a magyar állam fennhatósága terjedt ki négy éven keresztül. Felhasználom a vonatkozó jogszabályokat, levéltári dokumentumokat, valamint az eddig megjelent szakirodalmi forrásokat, amelyeknek - szándékom szerint - e dolgozat nem pusztán összefoglalása, hanem új megállapításokat tartalmazó szintézise.

Kulcsszavak: második bécsi döntés, Észak-Erdély, törvénykezés, bíróságok, bírók 
Debreceni Jogi Múhely 2021. (XVIII.) 3-4.

Debreceni Egyetem, Állam- és Jogtudományi Kar, Debrecen

(University of Debrecen, Faculty of Law, Debrecen)

DOI 10.24169/DJM/2021/3-4/3

\section{Előzmények}

A kiegyezés után néhány évvel létrejött Magyarországon az a négyszintû, háromfokú bírósági rendszer, amely kisebb-nagyobb változtatásokkal az 1940-es évek végéig fennmaradt. A struktúra nem változott, bár többször került sor bíróságok létrehozására vagy megszüntetésére, hatáskörük, illetékességük átszabására. Ez a kiforrott, polgári fórumrendszer állt fenn, amikor 1918-19-ben Románia hadserege fokozatosan megszállta Magyarországnak a Tiszától keletre fekvő területeit. Annak ellenére, hogy a békeszerződés megkötésére csak 1920 nyarán került sor, már 1918-ban megkezdődött a közigazgatás román állami fennhatóság alá vonása, ami a törvénykezési rendszert is elérte a következő év márciusában. Ahogyan a hadsereg egyre nyugatabbra vonult, úgy szűnt meg a magyar állami igazságszolgáltatás, és terjeszkedett egyre nagyobb területre a román. ${ }^{1}$ A bíróságok vezetőit leváltották, és az intézmények átadását követelték tôlük, akár a fegyveres erők bevonásával is. A magyar bírók legnagyobb része nem volt hajlandó húséget esküdni I. Ferdinánd királynak és a román államnak, így állásukat és nyugdíjukat elvesztették. (Veress, 2020b, pp. 151-161; Nánási, 2011, p. 31) 1924-ben, amikor az igazságszolgáltatás egységesítése elkezdődött, 141 olyan bíró tevékenykedett, aki 1918 előtt is bíróként szolgált (a korábbi bírói karnak nagyjából egyötöde). (Egry, 2020, p. 138)

Magyarország megmaradt területén a 34.500/1920. I. M. számú igazságügyminiszteri rendelet rendezte azoknak a településeknek a bírósági hovatartozását, amelyeknek korábbi fórumai a megszállás miatt már nem gyakorolhatták tevékenységüket a határ ezen oldalán. Az új magyar-román határ mentén 11 járásbíróságot érintett a jogszabály: az aradi, a berettyóújfalui, a fehérgyarmati, a gyulai, a mátészalkai, a nagykárolyi, a nagylaki, a nagyszalontai, a nagyváradvidéki, a szatmárnémeti és a székelyhídi kir. járásbíróságokat. A területváltozásokkal összefüggésben a 8.300/1923. M. E. számú kormányrendelet adott iránymutatást a bíróságok hatásköréről és illetékességéről, amelynek hatálya kiterjedt azokra a polgári peres és nemperes ügyekre, valamint azokra a büntetőügyekre, amelyekben a békeszerződés rendelkezései értelmében külföldi állampolgárrá vált személy volt félként érdekelve, vagy amely ügyek a békeszerződés alapján Magyarországtól elszakított területekkel álltak összefüggésben, különösen akkor, ha a bíróság (ügyészség) illetékessége az eljárás tárgyát képező ingó vagy ingatlan dolog fekvésén, az eljárásban érdekelt fél lakó- vagy tartózkodási helyén, a teljesítés (fizetés) helyén vagy a bűncselekmény elkövetésének helyén alapult. (Antal, 2017, pp. 32-37)

Két évtizeddel a trianoni békeszerződés után, 1940. augusztus 30-án a bécsi Belvedere palotában a németolasz döntőbíróság Magyarországnak ítélte azt a 43.492 négyzetkilométernyi területet, amely magában foglalta Erdély északi részét, valamint a tôle nyugatra és északra fekvő területeket Nagyszalontától Máramarosig. A Honvédség szeptember 5. és 13. között foglalta el a határozatban kijelölt területet, majd október 8-án lépett hatályba a román uralom alól felszabadult keleti és erdélyi országrésznek a Magyar Szent Koronához visszacsatolásáról és az országgal egyesítéséről szóló 1940. évi XXVI. törvénycikk, amely felhatalmazta a kormányt, hogy a törvényhozás további rendezéséig megtehesse mindazokat az intézkedéseket (törvényhozási tárgykörben is!), amelyek a visszacsatolt terület közigazgatásának, törvénykeezésének, közgazdaságának és általában egész jogrendszerének az ország fennálló jogrendszerébe való beillesztése végett szükségesek voltak (3. \$).

\section{A törvénykezési rendszer újjászervezése}

\subsection{Igaðságszolgáltatás a katonai kö̋igågatás idején}

A Honvédség bevonulásával párhuzamosan lépett hatályba a katonai közigazgatás és bíráskodás. Ezalatt a katonai törvényszékek láttak el ítélkezési feladatokat büntető ügyekben, majd 1940. november végétől a polgári bíróságok döntöttek magánjogi és büntető perekben egyaránt. Ehhez kevesebb mint három hónap alatt hatályba kellett léptetni (újra) az eljárásjogi törvényeket a szükséges átmeneti rendelkezésekkel, és a bírósági rendszer újjászervezése sem volt nélkülözhető. A katonai közigazgatás idejére az illetékes katonai

\footnotetext{
${ }^{1}$ A szatmárnémeti törvényszék elnökévé 1919 júniusában nevezte ki az új hatalom Erdős Ferenc törvényszéki bírót. (Sárándi, 2020, p. 79)
} 
Debreceni Jogi Múhely 2021. (XVIII.) 3-4.

Debreceni Egyetem, Állam- és Jogtudományi Kar, Debrecen

(University of Debrecen, Faculty of Law, Debrecen)

DOI 10.24169/DJM/2021/3-4/3

parancsnokok nevezték ki a bíróságok vezetőit, jellemzően a hivatalban volt helybeli bírák közül.

A meglévő román bíróságok hatásköre polgári peres és nemperes ügyekben (ahogyan büntető ügyekben) korlátozva maradt fenn, ugyanis elóbbi kategóriában csak olyan sürgős ügyekben járhattak el, amelyek tartáshoz és fenntartáshoz szükséges követelésekre irányultak. Nemperes ügyekben szintén a halasztást nem tűrő intézkedéseket lehetett teljesíteniük, amely körbe többek között a bizonyítás-felvétel és a követelések biztosítása végett szükséges intézkedések tartoztak. Továbbá telekkönyvi bejegyzéseket foganatosítani, árveréseket elrendelni és megtartani sem lehetett. Ugyancsak függőben kellett hagyni az iratok fellebbviteli bírósághoz terjesztését.

A polgári peres és nemperes ügyekben a megszálláskor hatályban volt jogszabályokat kellett alkalmazni azok kivételével, amelyek a főhatalom változása következtében a dolog természeténél fogva már nem voltak alkalmazhatók. Ezek helyett a magyar jog volt alkalmazandó. (Sárándi, 2016, pp. 318-319)

\subsection{Az uijjászervezett polgári birósági rendszer}

Bár szükséges volt ideiglenesen, korlátozott hatáskörrel fenntartani a román igazságszolgáltatási rendszert, nyilvánvaló volt, hogy a román állam bíróságainak rövid időn belül meg kell szűnniük az állami főhatalom megváltozása következtében.

„Tegnap délelött folyt le ünnepélyes küllöségek között a felszabadult és ïrraalakult kolozsvári itélótábla, törvényszéke, ügyéssség, továbbá az egyesitett járásbiróságok megalakulása." - adta hírül a nagyváradi Magyar Lapok. A visszacsatolást követően újjászervezték a közigazgatást, megoldást találtak az országgyúlési képviselet problémájára, azonban a harmadik hatalmi ág, a bíráskodás megszervezését is mihamarabb véghez kellett vinni, mivel a kor magyar polgári állama sem múködhetett volna a magánjogi viták rendezésére és az állami kényszermonopólium érvényesítésére szolgáló bírósági rendszer fennállása nélkül. Alig több mint két évtized telt csak el azóta, hogy a terület Románia részévé vált, így kínálkozott a lehetőség, hogy az 1920 előtti, és az anyaországban azóta is fennálló négyszintû, háromfokú bírósági rendszert újjászervezzék.

A 7.810/1940. M. E. számú kormányrendelet Kolozsvárott, Nagyváradon és Marosvásárhelyen ítélótáblák felállitását írta eló, valamint ezek mellett föügyészségek létrehozását. Tizenegy törvényszék, ezek mellett ugyanennyi ügyészség, valamint negyvenhét járásbíróság is létesült a rendelet alapján, amelyek a 61.800/1940. I. M. számú igazságügyminiszteri rendelet szerint november 26-án kezdték meg a múködésüket a polgári közigazgatás elindulásával egy napon. Az újra felállított törvénykezési rendszer azonban nem mutatott teljes egyezést a Trianon előttivel. A kézdivásárhelyi kir. törvényszéket és kir. ügyészséget a román fennhatóság alatt „tárgyilagos okokból” Sepsiszentgyörgyre helyezték át, és tekintettel arra, hogy utóbbi város Háromszék vármegye székhelye és fontos vasúti csomópont volt, a rendelet a magyar törvényszéket is ott tartotta felállítandónak. Emellett szólt még az a körülmény, hogy az első világháború előtti magyar kormányok is tervezték az áthelyezést. Szintén ebben a vármegyében egy kir. járásbíróságot pedig nem Nagyajtán hoztak létre, hanem Baróton, amely járási székhely volt, és a román járásbíróság is ott múködött. 1920 után helyi érdekekből vagy román nemzeti célokból több járásbíróságot is létesítettek, amelyek illetékessége kisebb területre és kevesebb személyre terjedt ki annál, hogy létük indokolt lett volna. Székhelyeik a következők voltak: Avasfelsőfalu, Dragomérfalva, Erdőszentgyörgy, Kápolnokmonostor, Kékes, Maroshévíz. A korábban ezekhez a román járásbíróságokhoz tartozott települések törvénykezési hovatartozását a 61.900/1940. I. M. számú igazságügyminiszteri rendelet határozta meg. Kivételt képezett az érmihályfalvai, hiszen ennek a területén negyvenezer lakos élt, székhelye vasúti csomópont és „élénk forgalmú hely" volt. Éppen ezért a kormány csak ezt ítélte fenntartandónak. Korábban Nagyváradon és Kolozsvárott is múködött városi és vidéki járásbíróság, azonban utóbbiak területe részben az új határ túloldalára esett. Továbbá korábban sem volt telekkönyvi hatóságuk, ezért takarékossági szempontból egyesítették őket a városi járásbíróságokkal.

A közigazgatási szervezet meghatározásakor az 1920-ban felosztott Bihar, Szatmár, Bereg és Ugocsa vármegyék újraegyesítése mellett döntött a kormány, ezzel szemben a bíróságok területének megállapításánál továbbra is jelentősége volt a trianoni határnak. A jogrendszerek közötti különbség, valamint a folyamatban

${ }^{2}$ Dr. Vékás Lajos itélótáblai elnök beiktatása, Magyar Lapok, IX. évf., 256. szám, (1940. november 28.) 6. 
Debreceni Jogi Múhely 2021. (XVIII.) 3-4.

Debreceni Egyetem, Állam- és Jogtudományi Kar, Debrecen

(University of Debrecen, Faculty of Law, Debrecen)

DOI 10.24169/DJM/2021/3-4/3

volt perek román nyelvú iratai indokolták azt, hogy az 1940. augusztus 30. előtti országterületen múködött bíróságok illetékességébe ne kerüljön visszacsatolt település, és az újra létrehozott bíróságokhoz se tartozzon anyaországi helység. A járásbíróságok területén a román fennhatóság alatti állapothoz képest nem változtattak (az említett néhány kivételtől eltekintve), hiszen a telekkönyvek és a telekkönyvi irattár elkülönítése és átszállitása hosszabb előkészületet kívánt. (MNL OL, K 27, 1940.10.30., pp. 12-15)

A kezdeti beosztásban később több változtatás történt. A máramarosszigeti kir. törvényszéket a 1.480/1941. M. E. számú rendelet alapján már 1941. április 1-től átcsatolták a nagyváradi kir. itélőtáblától a debrecenihez, bár akkor még a jogegységesítés - legalábbis a magánjog terén - éppen csak elkezdődött, és a folyamatban volt ügyek elintézése sem fejeződött be. Mindezek ellenére indokolt volt a változtatás, hiszen a korábban Csehszlovákiához tartozott rahói és técsői kir. járásbíróságok ehhez a törvényszékhez lettek beosztva, így a nagyváradi kir. ítélőtáblán szükség lett volna ruszinul tudó bírók alkalmazására, akik a debreceni kir. ítélőtáblán a többi kárpátaljai bíróság miatt már addig is dolgoztak. (MNL OL, K 27, 1941.02.21., pp. 6974) Itt jegyzem meg, hogy nem helytálló az a megállapítás, miszerint ebben az időben visszaállt a debreceni kir. itélőtábla Trianon előtti illetékessége. Ugyanis a szatmárnémeti és zilahi kir. törvényszékek ekkor a nagyváradi kir. itélőtáblához tartoztak, amelyek nélkül kizárólag a székhelyén múködő törvényszék és az ahhoz tartozó járásbíróságok fellebbviteli fórumaként szolgált volna. (Kengyel, 2017, p. 205)

1942 nyarára a fenti két akadály elhárult, így jelentősebb változtatásokat lehetett eszközölni az igazságügyi szervezetben. A 4.990/1942. M. E. számú rendelet a berettyóújfalui kir. járásbíróságtól több települést átcsatolt a nagyváradi kir. járásbírósághoz, ezzel együtt pedig előbbi is a nagyváradi kir. törvényszék és kir. ítélőtábla illetékességébe került. Trianon előtt is oda tartozott, azt követően pedig mindkét fellebbviteli fóruma Debrecenben volt. (Balogh, 2017, pp. 45-55) A mátészalkai és a fehérgyarmati kir. járásbíróságok visszakerültek a nyíregyházi kir. törvényszéktől a szatmárnémetihez, ezzel együtt szintén a nagyváradi kir. itélótáblához. A rendelet összesen 127 település járásbírósági hovatartozását változtatta meg a trianoni határ közelében és az 1940-ben visszatért országrészeken. Alapul szolgált az 1920 előtti beosztás, azonban figyelembe vették a közigazgatási határokat, a járásbíróságok székhelyeinek megközelíthetőségét és ügyterhét is. (MNL OL, K 27, 1942.08.21., pp. 10-43)

A korábbi épületek nagyrészt rendelkezésre álltak, mint például a kolozsvári Igazságügyi palota, ahol újra helyet kapott a járásbíróság, a törvényszék, az ítélőtábla és az utóbbi kettő mellett múködő ügyészség és föügyészség. A legsürgősebb helyreállítási munkák elvégzését, valamint a nem kincstári épületekben elhelyezett igazságügyi hatóságok elhelyezésének biztosítása céljából bérleti szerződések megkötését még 1940-ben kezdeményezte az igazságügyminiszter. ${ }^{3}$ A következő évben ilyen módon biztosítottak megfelelő helyet a besztercei kir. törvényszéknek, továbbá a bánffyhunyadi, a besztercei, az élesdi, az érmihályfalvai, a kovásznai, a nagyszalontai és az oklándi kir. járásbíróságoknak. Jelentősebb fenntartási, berendezési, felszerelési, helyreállítási és átalakítási munkálatokat végeztek a nagyváradi, a kolozsvári, a szatmárnémeti, a székelyudvarhelyi és a dési törvénykezési épületeken, valamint a nagybányai kir. járásbíróság épületén. ${ }^{4}$

Az Igazságügyi Közlönyben évente közzétett, ítélőtáblai tanácsok beosztása alapján megállapítható, hogy 1941-ben mindhárom ítélőtáblán két polgári és egy büntető tanácsot szerveztek, majd a következő évtől Kolozsvárott és Nagyváradon, 1943-tól Marosvásárhelyen egy-egy büntető tanáccsal több múködött. A polgári tanácsok számát csak Nagyváradon kellett megemelni eggyel, 1943-ra és 1944-re. Összehasonlításképpen megjegyzem, hogy a többi vidéki itélőtáblán: Debrecenben, ${ }^{5}$ Győrött, Kassán és Pécsett 1941-1944-ben három polgári és két büntető, Szegeden két (1943-től három) ${ }^{6}$ polgári és két büntető tanács ítélkezett. ${ }^{7} \mathrm{Az}$ ügyforgalom tekintetében elmondható, hogy 1941-ben a nyolc vidéki itélótábla közül a nagyváradihoz érkezett a legtöbb polgári ügy, összesen 1449, míg a büntetőügyek száma (495) alapján az utolsó előtti helyre volt sorolandó. Ehhez a fórumhoz 1941-ben jóval több, 1942-ben alig kevesebb polgári

\footnotetext{
3 A m. kir. kormány 1940. évi müködéséról és az ország közállapotairól szólójelentés és statisztikai évkönyv. Budapest, 1943. 70.

4 A m. kir. kormány 1941. évi müködéséröl és az ország közállapotairól sqoóló jelentés és statisztikai évkönyv. Budapest, 1943. 74.

5 Annak ellenére, hogy a máramarosszigeti kir. törvényszék fellebbviteli fóruma 1941. április 1-től a debreceni kir. ítélőtábla volt, a tanácsainak száma nem nőtt.

${ }^{6}$ Az 1941-ben visszacsatolt délvidéki területek legnagyobb részére a szegedi kir. itélőtábla illetékessége terjedt ki.

7 Személyi hirek. Igazságügyi Közlöny, L. évf., 1941/1. 38-40.; Személyi hirek. Igazságügyi Közlöny, LI. évf., 1942/1. 3437.; Személyi birek. Igazságügyi Közlöny, LII. évf., 1943/1. 32-35.; Személyi hírek. Igazságügyi Közlöny, LIII. évf., $1944 / 1$. $40-42$.
} 
Debreceni Jogi Múhely 2021. (XVIII.) 3-4.

Debreceni Egyetem, Állam- és Jogtudományi Kar, Debrecen

(University of Debrecen, Faculty of Law, Debrecen)

DOI 10.24169/DJM/2021/3-4/3

ügy érkezett, mint a két erdélyi ítélőtáblához összesen, így indokoltnak tekinthető a harmadik polgári tanács felállítása. Annak ellenére, hogy a marosvásárhelyi kir. itélótábla előtt 1942-ben 782 bủnügy várt elintézésre, a kolozsvári kir. ítélótábla előtt pedig csak 500, utóbbi helyen egy évvel hamarabb állították fel a második büntető tanácsot, a nagyváradival egy időben. ${ }^{8}$

\section{A „rekrutált bírói kar”}

Bírói vagy ügyészi kinevezéseket 1943. december 31-ig ideiglenes jelleggel azok is kaphattak, akik 1940. augusztus 30-án a román jogszabályok alapján erre alkalmasak voltak, illetve azok is, akik jogtudori oklevél birtokában valamely román ügyvédi kamaránál legalább hat évig be voltak jegyezve ügyvédként. Ezen rendelkezés szükségességét az indokolhatta, hogy ilyen rövid idô alatt nem lett volna lehetséges kizárólag az anyaországi szabályozás alapján a szükséges számú bírót kinevezni, illetve a hatályukban fenntartott jogszabályokat a helyi jogászok már ismerték és alkalmazták. Azonban sok ügyvéd nem rendelkezett ügyvédi vagy azzal egyenlő értékủ más vizsgával (a román jogszabályok 1925 és 1931 között nem követelték meg), így „ą igą̧ágszolgáltatás magasabb sæinvonalának biztositása végett” szükséges volt a legalább hatévi gyakorlat. (MNL OL, K 27, 1940.10.30., pp. 15-16) Mindkét esetben meg kellett felelniük a magyar jogszabályok egyéb rendelkezéseinek. A Budapesti Közlönyben közzétett kinevezések alapján a következőket állapítottam meg: a kolozsvári kir. ítélótáblára ebben a korszakban kinevezett 16 bíró közül 6-an rendelkeztek a visszacsatolt területen illetőséggel, 10-en pedig az ország más részeiből származtak. Utóbbiak között több olyan bírót találunk, aki pályája során korábban is az 1940-ben visszatért területen szolgált, jellemzően Trianon előtt. Például dr. Farsang Endre, aki 1910-ben a kolozsvári kir. ítélőtábla kerületében joggyakornokként tevékenykedett, majd erdélyi és magyarországi bíróságok után 1940-41-tôl a kolozsvári kir. itélótábla bírája lett. A marosvásárhelyi kir. itélótáblán 17-ből 9, a nagyváradi kir. itélótáblán 23-ból 10 bírót tekinthetünk helybelinek. Az 56 bíróból mindössze öten szolgáltak korábban ítélőtáblán, 1-1 fő pedig a kir. Kúrián és a kir. Közigazgatási Bíróságon, tehát a többség számára szintbeli emelkedést jelentett a kinevezés. Közülük 22 bíró ítélkezett korábban törvényszéken (11-en tanácselnökként), valamint 11 járásbírósági elnök, 5 járásbíró, 8 ügyvéd és 1-1 itélőtáblai elnöki titkár, ügyész, jogakadémiai tanár folytatta karrierjét valamelyik említett ítelótáblán. Az észak-erdélyi jogászság rekrutációs bázisát jelentősen erősítette az 1940. évi XXVIII. törvénycikk, amely a Ferencz József Tudományegyetem Kolozsvárra való visszahelyezéséről rendelkezett, és a jog- és államtudományi kar fennmaradásáról is gondoskodott.

Némi problémát jelentett azoknak a segédbíróknak (albíróknak) az elhelyezése, akik Romániában a bírói kar tagjai voltak ${ }^{9}$, azonban a fóhatalom megváltozása következtében nem pályázhattak bírói állásokra, ugyanakkor bírósági titkárnak sem, csak fogalmazónak vették fel óket (ráadásul ideiglenes jelleggel), ami lefokozásként érte őket. (Sárándi, 2016, pp. 310-313) ${ }^{10}$ Magyarországon korábban a járásbíróságokon szolgáltak aljárásbírók, ekkor viszont már egységesen járásbíróknak nevezték ennek a fórumnak a bíróit.

Nagyívú bírói pályát futott be id. dr. Vékás Lajos, aki 1911-től ítélőtáblai tanácsjegyző albíró, 1913-től pedig járásbíró volt Kolozsvárott, ahol 1915-től 1919-ig törvényszéki bíróként szolgált, majd a „magánszektorban”

8 A m. kir. kormány 1941. évi müködéséröl és az ország közállapotairól szóló jelentés és statisztikai évkönyv. Budapest, 1943. 269.; Magyar Statisztikai Évkönyv. Új folyam, L. 1942. Magyar Kir. Központi Statisztikai Hivatal, Budapest, 1944. 274. A nagyváradi kir. ítélőtábla elnöke egy 17. bíró kinevezését kérte az ügyforgalomra tekintettel, aminek a kormányzó eleget is tett azzal, hogy 1943. április 20-án kinevezte dr. Sághi Mihály zilahi kir. törvényszéki tanácselnököt az említett ítélőtáblához. Ld. MNL OL, Igazságügyminisztériumi levéltár, K 577 Elnöki iratok (1867-1948), 4. cs. B8 t. 1943 , A nagyváradi kir. ítélőtábla elnökének javaslata a nagyváradi kir. ítélőtáblánál bírói állás betöltése tárgyában.

${ }^{9}$ Maros-Torda megye román törvényszékének 1938-ban keletkezett ítéletéből is látszik, hogy albíró törvényszéki tanácstag is lehetett. MNL OL, Igazságügyminisztériumi levéltár, K 583 Egyesített Királyi Kúria Általános iratai (18821944), 179. cs. 59. t., P. I. 2509/1943/13.

10 Az itt feltüntetett nyolc albíró közül ketten, Bokánszky (Bohánszki) László és Jusekutz (Issekutz) János 1939-ben kapták meg kinevezésüket Szászrégenbe, illetve Kőhalomra. A fizetésük 252 pengőnek felelt meg. Ld. MNL OL, Igazságügyminisztériumi levéltár, K 577 Elnöki iratok (1867-1948), 4. cs. B6 t. 1940, Kimutatás azokról a volt közszolgálati alkalmazottakról, akiket a katonai parancsnokságok magyar közszolgálatba nem vettek át; Utóbbi 1941tôl Besztercén bírósági fogalmazó, 1942-től kolozsvári járásbírósági titkár, majd Bánffyhunyadon, Kolozsvárott, a háború után pedig Dombóváron járásbíró volt. 1947-től a budapesti törvényszék, majd a Kúria bírájaként dolgozott 1953-ig. (Issekutz, 2016, pp. 12-14) 
Debreceni Jogi Múhely 2021. (XVIII.) 3-4.

Debreceni Egyetem, Állam- és Jogtudományi Kar, Debrecen

(University of Debrecen, Faculty of Law, Debrecen)

DOI 10.24169/DJM/2021/3-4/3

helyezkedett el a Minerva Rt. vezetőjeként (ekként a magyar nyelvú könyv- és lapkiadást szolgálta). 1940ben a kolozsvári kir. ítélótábla elnökévé nevezte ki az igazságügyminiszter, majd a kormányzó, amely tisztségét 1944-ig töltötte be. (Veress, 2020c, pp. 172-179; Veress, 2019a, pp. 7-9) Az elnök köszöntő beszédében „a magyar biró bivatásáról beszélt, elitélve ąt a korrupt szellemet, melynek búszéven át nemcsak szemtanuii, de áldozatai is voltunk. A nagyszabású beszéd után a birák bivatali fogadalmának. letétele következętt."11

Jelen korszak újjászervezett bíróságairól Fekete Andor marosvásárhelyi ügyvéd egy teljes fejezetben ír emlékirataiban. Tapasztalatai szerint az újjászervezett bíróságok ítélkezésének színvonala alul maradt a Trianon előtti szinthez képest, és mindössze néhány érdemes bíró munkája jelentett kivételt. „A biróságnak [marosvásárhelyi kir. ítélőtábla] dicséretére kell irnom åt, hogy itélkeęéseiben nem engedte magát elragadtatni az. ak.kor divatos áramlattól, amely Magyarország egyetlen problémáját a zsidókérdésben látta."Végül ekképp összegezte emlékeit: „Egyéni tisztesség és megkëzzelíthetetlenség dolgában azonban, mind a Magyarországról idehozott, mind az erdélyi jogászokeból rekrutált birói kar változatlanul kifogástalan volt.” (Fekete, 2019, pp. 177-179)

\section{A polgári peres és nemperes eljárások}

Ahogyan a bűnvádi eljárásra, úgy a polgári perrendtartásra vonatkozó jogszabály sem vesztette hatályát az 1920-as impériumváltás következtében: a korábban Magyarországhoz tartozott területeken továbbra is a Plósz-féle Pp-t alkalmazták a bíróságok, így amikor 1940-ben az északi és keleti részek visszatértek a magyar állam fennhatósága alá, a polgári eljárási szabályok nagy vonalakban ugyanazok voltak, mint az anyaországban. ${ }^{12} \mathrm{~A}$ bíróságok a polgári peres eljárás és egyes nemperes eljárások szabályozása tárgyában hozott 8.220/1940. M. E. számú kormányrendeletben foglalt eltérésekkel alkalmazták a polgári perrendtartásról szóló 1911. évi I. törvénycikket. Ez a kiegészítő jogszabály sokkal több eltérést és átmeneti rendelkezést tartalmazott, mint a büntetőbíráskodás megkezdését tárgyaló 7.980/1940. M. E. számú rendelet, hiszen a Pp. által szabályozott eljárások is sokszínúbbek voltak.

A román bíróságok elôtt megkezdett ügyeket automatikusan áttették az illetékes magyar bíróságokhoz, azonban, ha az ügyben a magyar jog szerint hatósági eljárásnak volt helye, akkor a megfelelő hatósághoz. Romániában már léteztek munkaügyi különbíróságok; ezeknek a folyamatban lévő ügyeiben is a rendes bíróságok jártak el a továbbiakban.

Míg a büntetőeljárás tekintetében az adott földrajzi területre való bevonulás számított jelentôs dátumnak, addig a polgári eljárásokban a döntés kihirdetésének napja, azaz 1940. augusztus 30. jelentett választóvonalat. Például az ennél korábban megkezdődött, de le nem járt határidők november 26-án, a bíróságok munkájának megkezdése napján újra kezdődtek.

A rendelet a pertárgyérték és az elveszett iratok pótlása mellett kitért a házassági perekre és a végrehajtási záradékkal ellátott váltók kérdésére is, valamint rendelkezett olyan jogorvoslati lehetőségekről, mint a fellebbvitel és a perújitás. Nem hagyhatjuk figyelmen kívül, hogy az 1940. évi XXVI. törvénycikk akképp rendelkezett, hogy a kormány további rendelkezéséig a román jogszabályok maradtak hatályban a visszacsatolt területen. Ekkor sem a bíróságokat, sem a jogkereső közönséget nem terhelték azzal, hogy az eljárási szabályokban történt változások mellett az anyagi jogi szabályok megváltozására is legyenek figyelemmel. Utóbbira a következő években került sor, ami az Osztrák Polgári Törvénykönyv erdélyi nyolc évtizedes alkalmazásának vetett véget, úgy, hogy nem kódexet, hanem egy sor kisebb jogszabályt és (főleg írott) szokásjogot léptetett a helyébe.

\section{Záró gondolatok}

Ahogyan a fentiekből egyértelmúen kiderül, Magyarország vezetése minden szükséges intézkedést megtett annak érdekében, hogy az 1940-ben visszatért területeken kiépítse a magyar törvénykezési rendszert, és beillessze az ország többi részén fennállóba. A legszükségesebb ügyekben már a katonai bíróságok is

\footnotetext{
${ }^{11}$ Dr. Vékás Lajos itélótáblai elnök beik.tatása, Magyar Lapok, IX. évf., 256. szám, (1940. november 28.) 6.

12 Dél-Erdélyben 1943-ban lépett hatályba az 1865-ös román polgári perrendtartás. (Veress, 2019b, pp. 101-103; Veress, 2020a, p. 577)
} 
Debreceni Jogi Múhely 2021. (XVIII.) 3-4.

Debreceni Egyetem, Állam- és Jogtudományi Kar, Debrecen

(University of Debrecen, Faculty of Law, Debrecen)

DOI 10.24169/DJM/2021/3-4/3

eljárhattak, de kevesebb mint három hónappal a bevonulás után a polgári igazságszolgáltatás is megkezdte múködését. Látható, hogy a Trianon előtti szervezet fontos mintául szolgált - nemcsak a hagyománytisztelet, hanem a szervezet kiforrottsága miatt -, de a jogalkotó nem ragaszkodott mereven a régi megoldáshoz, hanem észszerú okból változtatott is rajta. Az eljárásokra vonatkozó részletes átmeneti rendelkezések azt biztosították, hogy a magyar polgári igazságszolgáltatás kapcsolódni tudjon a második bécsi döntés időpontjáig múködött román igazságszolgáltatáshoz. Némiképp megkönnyítette az átállást, hogy a polgári perjog szabályanyaga nagyrészt megegyezett az anyaországival. Az itélótáblák ügyterhének a növekedésével nőtt az ítélkező tanácsok száma, ezzel együtt a bírói kar létszáma is. A fennállt, de fokozatosan megszüntetett jogrendszerbeli különbségekre tekintettel fontos volt, hogy a bírák egyik része a helybeli, a másik része az anyaországi jogot ismerje jól, az igazságszolgáltatás színvonalának biztosítása végett. A személyi feltételeken túl az infrastrukturális körülményekre is fordított figyelmet az igazságügyi kormányzat.

A kiépített rendszer talán sikeresen múködött volna tovább, ha a külső körülmények nem vetettek volna véget a magyar állam fennhatóságának. Miután 1944 őszén a szovjet és a román hadsereg megszállta az 1940ben visszatért országrészeket, a következő évben a moszkvai fegyverszüneti egyezményben foglaltak teljesítése végett Magyarország visszavonta hivatalnokait a visszacsatolások előtti területére, és hatályon kívül helyezte a visszacsatolásokra vonatkozó jogszabályokat. Ennek ellenére az akkor szerzett tapasztalatok felhasználhatók a jelenkori bírósági szervezet és az eljárásjogok módosításainál is.

\section{Forrásjegyzék}

Könyvek

FEKETE Andor (2019) Közélet és kaszinó. Marosvásárhely, Mentor Könyvek Kiadó. 347. p. ISBN 978606-8861-33-3

SÁRÁNDI Tamás (2016) Levezényelt visszacsatolás - A magyar katonai közigazgatás Észak-Erdélyben, 1940. Csíkszereda, Pro-Print Könyvkiadó. 623. p. ISBN 975-606-556-091-8

Könyvrészletek

BALOGH Judit (2017) Mozaikok a Berettyóúffalui Királyi Járásbíróság történetéből (1872-1949). In: MEGYERI-PÁLFFI Zoltán (szerk.) A jogszolgáltatás története Berettyóújfaluban. Debrecen, Debreceni Törvényszék. pp. 45-55. ISBN 978-963-12-8603-8

EGRY Gábor (2020) Zárványok, hagyományok, szakemberek. A magyar közigazgatás és Nagy-Románia múködése. In: L. BALOGH Béni (szerk.) Trianon és a magyar közigazgatás. Budapest, Magyar Kormánytisztviselői Kar - Magyar Nemzeti Levéltár. pp. 131-150. ISBN 978-963-631-296-1

KENGYEL Miklós (2017) A magyar bírósági szervezet a két világháború között. In: BALOGH Judit et al. (szerk.): Studia in honorem István Stipta. Budapest, Károli Gáspár Református Egyetem Állam- és Jogtudományi Kar. pp. 195-207. ISBN 978-963-9808-74-4

SÁRÁNDI Tamás (2020) Konszolidáció után konszolidáció. Szatmárnémeti közigazgatásának változásai 1918-1924 között. In: L. BALOGH Béni (szerk.) Trianon és a magyar közigazgatás. Budapest, Magyar Kormánytisztviselői Kar - Magyar Nemzeti Levéltár. pp. 69-85. ISBN 978-963-631-296-1

VERESS Emőd (2019a) Köszöntő. In: VERESS Emőd (szerk.) AD SALUTEM CIVIUM INVENTAS ESSE LEGES Tisztelgő kötet Vékás Lajos 80. születésnapjára. Kolozsvár, Forum Iuris. pp. 7-9. ISBN 978606-9061-15-2

VERESS Emőd (2020a) 6.4.1. (j) A polgári eljárásjog modernizációjának kísérlete. In: VERESS Emőd (szerk.) Erdély jogtörténete, 2. bővített és javított kiadás. Budapest - Kolozsvár, HVG-Orac Könyvkiadó Forum Iuris Könyvkiadó. pp. 576-577. ISBN 978-606-9061-20-6

VERESS Emőd (2020c) Vékás Lajos: A törvényszéktől a könyvkiadásig, az ítélőtáblától a téglagyárig. In: VERESS Emőd (szerk.) ERDÉLYI JOGÁSZOK, Jogászportrék I. Kolozsvár, Forum Iuris Könyvkiadó. pp. 172-179. ISBN 978-606-9061-23-7 
Debreceni Jogi Műhely 2021. (XVIII.) 3-4.

Debreceni Egyetem, Állam- és Jogtudományi Kar, Debrecen

(University of Debrecen, Faculty of Law, Debrecen)

DOI $10.24169 / \mathrm{DJM} / 2021 / 3-4 / 3$

Folyóiratcikkek

ANTAL Tamás (2017) A trianoni békeszerződés hatásai a királyi ítélőtáblákra - különös tekintettel a szegedire. Acta Universitatis Szegediensis, FORVM, Acta Juridica et Politica, VII. évf. 1. sz. pp. 31-44. ISSN 2063-2525

ISSEKUTZ Sarolta (2016) 100 évvel ezelőtt, 1916. március 3-án született dr. Issekutz János. Erdélyi Örmény Gyökerek, XX. évf. 222. sz. pp. 12-14.

NÁNÁSI László (2011) Az I. világháború hatása és következményei a magyar igazságügyi impériumra. Jogtörténeti Szemle, XIII. évf. 1. sz. pp. 27-42.

VERESS Emőd (2019b) A jogegységesítés útvesztői. Polgári perjog Erdélyben 1918/1920 és 1945 között. Rubicon, XXX. évf. 9-10. sz. pp. 101-103.

VERESS Emőd (2020b) Erdély 1919-ben: a magyar igazságszolgáltatástól a román igazságszolgáltatásig. Erdélyi Jogélet, I. évf. 2. sz. pp. 151-161. ISSN 2734-7095, https:/ /doi.org/10.47745/ERJOG.2020.02.08

Jogszabályok

1940. évi XXVI. törvénycikk a román uralom alól felszabadult keleti és erdélyi országrésznek a Magyar Szent Koronához visszacsatolásáról és az országgal egyesítéséről

1940. évi XXVIII. törvénycikk a Magyar Királyi Ferenc József Tudományegyetem újjászervezésérôl és a Magyar Királyi Horthy Miklós Tudományegyetem felállításáról

A m. kir. minisztérium 8.300/1923. M. E. számú rendelete polgári és büntető ügyekben a m. kir. bíróságok és ügyészségek hatáskörének és illetékességének a trianoni békeszerződéssel összefüggő szabályairól

A m. kir. minisztérium 7.810/1940. M. E. számú rendelete a keleti és erdélyi országrésznek a Magyar Szent Koronához visszacsatolásával kapcsolatos igazságügyi szervezeti rendelkezések tárgyában

A m. kir. minisztérium 7.980/1940. M. E. számú rendelete a Magyar Szent Koronához visszacsatolt keleti és erdélyi területen a magyar polgári büntetőbíráskodás működésének megkezdése tárgyában

A m. kir. minisztérium 8.220/1940. M. E. számú rendelete a Magyar Szent Koronához visszacsatolt keleti és erdélyi országrészen a polgári peres eljárás és egyes nemperes eljárások szabályozása tárgyában

A m. kir. minisztérium 1.480/1941. M. E. számú rendelete a máramarosszigeti kir. törvényszék, valamint a rahói és a técsői kir. járásbíróság törvénykezési átcsatolásáról

A m. kir. minisztérium 4.990/1942. M. E. számú rendelete egyes kir. járásbíróságok és községek törvénykezési átcsatolása tárgyában

A m. kir. igazságügyminiszter 34.500/1920. I. M. számú rendelete egyes kir. bíróságok hatóságának az eljárásban akadályozott bíróságok területére kiterjesztése tárgyában

A m. kir. igazságügyminiszter 61.800/1940. I. M. számú rendelete a Magyar Szent Koronához visszacsatolt keleti és erdélyi országrészen a királyi bíróságok és a királyi ügyészségek működésének megkezdése tárgyában

A m. kir. igazságügyminiszter 61.900/1940. I. M. számú rendelete a Magyar Szent Koronához visszacsatolt keleti és erdélyi országrész egyes községeinek törvénykezési beosztása tárgyában

Levéltári források

Magyar Nemzeti Levéltár Országos Levéltára (a továbbiakban: MNL OL), Miniszterelnökségi levéltár, K 27 Minisztertanácsi jegyzőkönyvek (1867-1944), 1940.10.30.

MNL OL, K 27, 1941.02.21.

MNL OL, K 27, 1942.08.21.

MNL OL, Igazságügyminisztériumi levéltár, K 583 Egyesített Királyi Kúria Általános iratai (1882-1944), 179. cs. 59. t., P. I. 2509/1943/13.

MNL OL, Igazságügyminisztériumi levéltár, K 577 Elnöki iratok (1867-1948), 4. cs. B6 t. 1940, Kimutatás 
Debreceni Jogi Mühely 2021. (XVIII.) 3-4.

Debreceni Egyetem, Állam- és Jogtudományi Kar, Debrecen

(University of Debrecen, Faculty of Law, Debrecen)

DOI 10.24169/DJM/2021/3-4/3

azokról a volt közszolgálati alkalmazottakról, akiket a katonai parancsnokságok magyar közszolgálatba nem vettek át

MNL OL, K 577, 4. cs. B8 t. 1943, A nagyváradi kir. ítélőtábla elnökének javaslata a nagyváradi kir. ítélőtáblánál bírói állás betöltése tárgyában

Egyéb források

A m. kir. kormány 1940. évi működéséről és az ország közállapotairól szóló jelentés és statisztikai évkönyv. Budapest, 1943.

A m. kir. kormány 1941. évi működéséről és az ország közállapotairól szóló jelentés és statisztikai évkönyv. Budapest, 1943.

Magyar Statisztikai Évkönyv. Új folyam, L. 1942. Magyar Kir. Központi Statisztikai Hivatal, Budapest, 1944.

Személyi hírek. Igazságügyi Közlöny, L. évf. 1941/1. pp. 38-40.

Személyi hírek. Igazságügyi Közlöny, LI. évf. 1942/1. pp. 34-37.

Személyi hírek. Igazságügyi Közlöny, LII. évf. 1943/1. pp. 32-35.

Személyi hírek. Igazságügyi Közlöny, LIII. évf. 1944/1. pp. 40-42.

Dr. Vékás Lajos ítélőtáblai elnök beiktatása, Magyar Lapok, IX. évf., 256. szám, (1940. november 28.) p. 6. 